\title{
Physicians in the double role of treatment provider and expert in light of principle- based social insurance medical ethics
}

\author{
Hans Magnus Sollia \& António Barbosa da Silva ${ }^{b}$ \\ ${ }^{a}$ Research Unit, Division of Mental Health and Addiction, Vestfold Hospital Trust, \\ Tønsberg, Norway, hmsolli@online.no \\ ${ }^{\mathrm{b}}$ Ansgar University College and Theological Seminary, Kristiansand, Norway, \\ dasilva@angarskolen.no
}

DOI: http://dx.doi.org/10.5324/eip.v13i2.2911

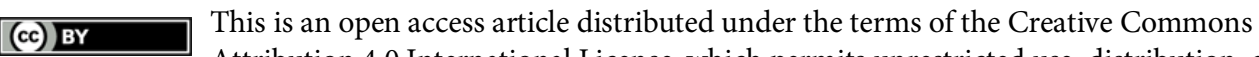
Attribution 4.0 International License, which permits unrestricted use, distribution, and reproduction in any medium, provided the original author and source are credited.

GPs serve in a double role of treatment provider and expert in certain social insurance systems, such as the Norwegian one. Some physicians assert that the ethical obligations of the two roles conflict with each other. The objective of this article is to show that social insurance medical ethics (SIME), which are based on recognised principles of medical ethics, unite the physicians' obligations associated with these roles. The method applied is a medical ethics conceptual analysis. The material consists of literature on normative SIME. The study shows that SIME expands the role of the treatment provider to a wider societal context. Here, physicians should attempt to balance the perspectives of sympathy with empathy, as treatment providers, with the impartiality in their role as experts. Five principles of medical ethics are fundamental. Respect for human dignity is the overarching principle of medical ethics. The four others are nonmaleficence, beneficence (including soft paternalism), autonomy, and social justice. The article discusses two areas where it is asserted that the roles of treatment provider and expert conflict with each other: the application of beneficence and justice, and the duty of confidentiality versus the duty to provide information to the National Insurance service. The study concludes that there are no basic ethical conflicts between the two roles. The ethical problems that may arise when exercising this duality should be viewed in the same way as other ethical problems in medicine. Actual application and balancing of the principles may necessitate negotiations between patients and physicians.

Keywords: dual roles, professionalism, deliberation, impartiality, medical principle ethics, values of welfare state

\section{Introduction}

Research conducted in several welfare states, including Norway, documents how physicians often view medical certificates as problematic. This is a matter of handling disagreements with patients about whether medical certificates are warranted or not, deciding the certificates' correct duration, assessing the patient's capacity for work, 
and collaborating with other parties like employers and the local National Insurance office. Some physicians believe that conflicts may arise between the duality of the roles of patient treatment provider and expert when dealing with the National Insurance system (Wynne-Jones, Mallen, Main and Dunn 2010).

The Medical Ethics Council of the Norwegian Medical Association found that the many complaints pertaining to physicians' expert statements were often associated with a lack of clarity in relation to the role of the physician and his/her obligations in the situation in question. The following new rule was therefore introduced in the Code of Ethics for Doctors (2015: I. General provisions, Section 2):

Doctors have different roles as treatment provider, expert and administrator of welfare benefits. [...] A clear distinction must be made between their roles of treatment provider and expert. Doctors are responsible for providing necessary and appropriate information about their role and the purpose of the contact.

A clarification has yet to be provided of the above-mentioned problem regarding roles that is rooted in medical ethics. Mæland's (2016) guide to social insurance medicine in Norway is widely used and outlines a presumably widespread perception. He considers the roles of the treatment provider and the expert to be separate, which calls for different types of ethics. Mæland (2016: 27) writes the following about the role of the physician as an expert:

The ordinary requirements and rules that govern the physician as a treatment provider do not apply to [the role of the expert]. For example, the duty of confidentiality and the obligation to always act in the patient's best interests do not apply (author translation).

Here, he asserts that the role of the expert is not subject to the ordinary ethical requirements that govern the physician as a treatment provider. According to the quote above, the obligations of the GP as an expert may conflict with his/her duties as a treatment provider, for example between the duty of confidentiality and the duty to act in the patient's best interests. We believe that this entails an assertion that the ethics governing the role of expert and treatment provider conflict with each other. The guide we cited elaborates further on its view by asserting that the physician as an expert must:

present the medical facts in the case and provide his/her best assessment of them, irrespective of whether this is in the favour or disfavour of the person in question. [...] Seeking to achieve objectivity and neutrality is thus an ideal for experts. A medical expert must represent his/her field and none of the parties (author translation) (Mæland 2016: 28).

Our interpretation of the quotes above is that the role of expert entails ethics which cancel out the physician's clinical relationship with the patient in favour of a professionalism which should be objective and neutral when dealing with the state and the patient. This cannot be an ethically satisfactory solution for GPs. A GP who is an expert on behalf of a patient he/she has treated can hardly disregard his/her obligation to protect the patient's best interests. GPs are also aware that objectivity is a controversial topic in our time (Solli \& Barbosa da Silva, 2018). They may agree that expertise requires them to be objective and impartial when assessing a person. However, they also know that expertise cannot be ethically value-neutral in relation to the patient's best interests. The guide's view of duties appears to be at odds with medical ethics. 
This article posits that social insurance medical ethics (hereinafter SIME), which is based on recognised principles of medical ethics, unite the ethical obligations of physicians in the roles of treatment provider and expert. SIME allows the ethical obligations in the dual role of treatment provider and expert to be exercised within the frames of principles of medical ethics, without the obligations coming into conflict with each other. The article's starting-point is the relationship between GPs, patients and the social welfare regime in a Norwegian context. The article is presumed to be of interest to the welfare regimes of other countries where physicians or other clinicians serve in the dual role of treatment provider and expert.

\section{Material and method}

We searched for relevant literature on normative SIME from 1990 until 2016 in the Medline, Psychinfo, Ethicsweb, Philpapers and Cochrane databases. The search terms we used were 'social security/insurance medicine', 'ethics', 'physician's role', 'disability/work capacity evaluation', 'expert testimony' and combinations of these. We found only seven articles in English, German, Swedish and Norwegian (Toon 1992; Bruusgaard 1996; Terum \& Nergård 1999; Solli 2003; Solli, Barbosa da Silva, Lie \& Bruusgaard 2005; Rudebeck 2010; Seger \& Nüchtern 2015). We found a further six sources in a separate archive (WHO 2001; Westrin \& Nilstun 2002; Meland 2005; Solli 2007; Lynöe, Wessel, Olsson, Alexanderson and Helgesson 2011; Nüchtern and others 2015). None of these sources presents a consistent normative SIME. We also draw on other relevant ethical literature to achieve the goals of the article.

Our method is a medical ethics conceptual analysis used to clarify ethical principles and examine how they logically relate to each other, both in theory and practice.

\section{Welfare state, work and functioning}

First, we would like to place SIME in a societal context. We view the welfare state as a democratic compromise between a capitalist, individualist market economy and a public, communally-funded and guaranteed distribution of economic resources. The objective of the welfare state is to safeguard the welfare of all citizens, enabling them to lead a reasonably good life on their own terms, with access to public goods, liberty, and offering social justice. The obligations and the rights of the citizens of the welfare state depend on a functioning, productive and sustainable economy (Steigleder 2014). Work is the crux of such an economy. Most people are expected to meet their needs through work, and have an obligation to do so.

From a medical perspective, work is good for both health and welfare, if the working conditions are fair. However, some people are ill or have disabilities that prevent them from working (Waddell \& Burton 2006: 36-38). We follow Gough (2017: 185), asserting that from an ethical perspective, work contributes to selfrespect, cognitive development, socialisation related to meaningful tasks, participation in productive work and collective well-being. SIME follows WHO's International Classification of Functioning, Disability and Health (2001) (hereinafter ICF) by focusing particularly on patients' health in terms of functional ability and social participation, including labour participation.

From this point of view, all physicians should focus on functional capacity and capacity for work in their role as treatment provider. Special to the role of the expert 
is that the physician has a mandate from the National Insurance Service (hereinafter NIS) to assess patients' functional capacity and capacity for work in terms of the rights and requirements in welfare legislation. This wider societal perspective expands the obligations of the role of treatment provider (Rudebeck 2010).

\section{Balancing the perspectives of sympathy and impartiality}

In order to integrate the ethics of the role of clinical treatment provider with the ethics of the role of expert, it is necessary to consider and familiarise oneself with the importance of the perspectives of sympathy and impartiality in human social life. Studies of the natural history of human morality have shown that the two different perspectives have been fundamental to the evolution of cooperation among humans (Tomasello 2016: 1-5). These perspectives are also fundamental in medical ethics (Beauchamp \& Childress 2013: 92-4; Solli 2007: 230f). The perspective of sympathy dominates personal relationships such as families. 'The capacity for sympathy enables us to enter into, however imperfectly, the thoughts and feelings of another being. Through sympathy, we form a concern for the other's welfare' (Beauchamp \& Childress 2013: 92). Sympathy is based on empathy and compassion and is often used in clinical work, including clinical social insurance medicine. Empathy is the ability to understand and share the feelings of another. A perspective of sympathy, with empathy, is the main perspective of the treatment provider.

However, society also needs a perspective that requires us to take equal consideration of each other's interests. This is the perspective of fairness or justice, which includes the perspective of impartiality. The perspective of impartiality covers decisions made by individuals working together in ways that foster the common good, while also attempting to consider each person's special interests, feelings and basic needs equally. Decisions on the impartial distribution of burdens and benefits should therefore be made at some mental and emotional distance from any existing personal relations to the situation in question. The perspective of impartiality is the main perspective of the GP as an expert. Taking a step back makes it possible to view a patient's situation dispassionately and to consider their everyday life, working life and the context in question. An expert assessment should be impartial and not depend on which specific person is involved.

German social medicine uses the concept of empathy to explain the relationship between the perspectives of sympathy and impartiality: 'Empathy and interest in the individual are a prerequisite of expertise for social insurance medicine. They are not in opposition to the neutrality of the expert (= impartiality, author translation and remark) (Nüchtern and others 2015: 582f).

A unique characteristic of SIME practice is that it should balance the perspectives of sympathy and impartiality to a greater extent than regular clinical practice does. Sympathy, along with empathy, should thus be balanced with impartiality as a prerequisite for good social insurance medicine practices in a welfare state.

\section{A SIME based on principles}

We will now review a recognised system of medical ethics that we believe could provide a foundation for SIME. Westrin and Nilstun (2002) assert that SIME should consist of ethical principles. Ethical principles protect and defend corresponding ethical values. We draw on Beauchamp and Childress' (2013) renowned principles of 
biomedical ethics, as proposed by Seger and Nüchtern (2015). We must note that principles are not absolute standards that do not allow compromises with other principles. Principles are abstract and must be elaborated on in order to provide guidance in a given situation. It must also be possible to relate them to other relevant principles, and an assessment must be made of whether an actual conflict exists between them or whether relevant principles should be balanced by designating one principle as taking precedence over the others. The four basic principles of medical ethics are: nonmaleficence, beneficence, autonomy and justice (Beauchamp \& Childress 2013). These principles defend some basic ethical values in the welfare state. Needs satisfaction in the welfare state is addressed through the first two principles, which state that treatment must not harm the patient and that it should cover the patient's medical needs. Liberty is safeguarded by the principle of respecting the patient's autonomy and fundamental rights. The basic realisation of justice in social insurance is social justice, as we explain it below. We will add a fifth principle, the principle of human dignity, in line with UNESCO's Universal Declaration on Bioethics and Human Rights (UNESCO 2005: art. 3). Human rights are now entrenched in welfare law. They belong to 'the core values that are and will be fundamental in Norwegian society' (author translation) (Kjønstad, Syse and Kjelland 2017: 89). We will now provide a brief account of the five principles cited in a SIME context.

\section{The principle of human dignity}

The Code of Ethics for Doctors (2015: I General provisions, Section 1) states, 'A doctor shall base his practice on respect for fundamental human rights'. In clinical practice, respect for human dignity or human rights means encountering, viewing, listening to and acknowledging the patient as having the same dignity that is inherent in all people. Respect for human dignity is linked to respect for individual identity, because all people have a unique identity (Nordenfelt 2004). The individual's free choices in life should therefore be respected. Dignity, identity and integrity are closely linked, so that to violate one of them is to violate the others (Tranøy 2005: 38).

Human rights give patients the right to participate in decisions regarding themselves. The first step in participation is to acknowledge the patient's perspective. This means, for example, that the physician checks whether he/she has understood the patient correctly. Such practices have proven to provide room for disagreement between the patient and the physician without this resulting in a conflict between them (Steihaug, Gulbrandsen and Werner 2012). In social insurance medicine, the physician and patient may, for example, disagree on the physician's assessments regarding the patient's future capacity for work. We will elaborate on steps related to participation regarding the follow-up of people on sick leave and the writing of certificates below.

The ICF asserts a human right that is often neglected: 'the full participation of people with disabilities in all areas of social life' (WHO 2001: 20). Physicians should also work to promote their disabled patients' participation in working life and other social life.

The principle of human dignity is the only principle that should not be trumped by another principle of medical ethics in an actual decision-making situation. This makes it the leading SIME principle. 


\section{Nonmaleficience}

The norm to do no harm to the patient is also necessary in social insurance medicine. Perhaps most importantly, the physician should refrain from intervening in ways that may have a detrimental effect on the patient's capacity for work (Waddell \& Burton 2006). Such harm may be done if the physician puts a patient on full sick leave indefinitely when an illness is not serious, and the physician has no strategy for the patient to return to work. In the event of serious illness, it is important for experts to avoid writing a more negative prognosis on a certificate than what was communicated to the patient. The physician should also avoid writing medical certificates that are so uninformative that the patient risks having a legitimate case denied by the NIS on the wrong grounds. The ideal is that social insurance medical practice must not damage the relationship between physicians and patients (Solli 2007: 377). Sick leave is an example of a conflict that could arise between the GP and patient. The conflict might be about how the physician and the patient view the situation differently in relation to the legal rules. When ethics are involved, a conflict between ethical principles is unlikely, but views may differ on how to apply them to the situation in question. Communication skills are important in such situations (Silverman, Kurtz and Draper 2013).

\section{Beneficence}

Patient needs are considered through the physician's obligation to contribute to the patient's welfare from a medical perspective, which implies the principle of beneficence. Beneficence is the established term for physicians' obligation to help their patients by virtue of their role as treatment provider (Beauchamp \& Childress 2013: 202-203). The obligation is often referred to as acting in the patient's best interests or, in other words, meeting their medical needs. Two relevant needs in social insurance medicine are receiving clinical help to improve one's functional ability and capacity for work, and receiving an expert assessment of whether one meets the medical requirements for receiving welfare benefits, which safeguard the right to financial security. However, it is important to be aware that meeting a need in the short term (like granting a disability benefit and thus possible passivisation) may be detrimental in terms of meeting other basic needs in the long term (like physical activity and participation in society) (Bruusgaard 1996). This is why it is important in some situations for the physician to bring up the question of what constitutes the patient's best interests in the long term.

\section{Paternalism}

An important ethical question is whether the patient, the physician or the authorities should determine what is in the patient's best interests or what they need. Kjønstad and others (2017: 29) write: 'To a great extent, the welfare state is based on paternalistic thinking. This is often based on the idea that people do not always know what is best for themselves, and therefore are not able to protect their own interests' (author translation). Dworkin (1999: 115) defines paternalism as 'the interference with a person's liberty of action justified by reasons referring exclusively to the welfare, good, happiness, needs, interests or values of the person being coerced'. Dworkin (1999: 128) also asserts that paternalistic legislation is legitimate as long as the authorities present evidence of the harmful effects (or the positive consequences) 
to be avoided (or achieved) by means of professional and political interventions. Similar reasoning must be applied to social insurance. An open and critical social debate should be able to protect citizens' freedom of action within paternalistic welfare legislation. We believe that a certain level of paternalism on the part of the authorities, as an expression of how democracy views what is in the best interests of citizens and the community, can be defended ethically due to the common benefits afforded by welfare. One example is the current view that having as many people as possible continue working for as long as possible until a specific retirement age (work-first strategy) is in the best interests of individual citizens and the community.

Paternalism is primarily expressed in how the authorities formulate legal rules. It can also colour employees' attitudes and ways of communicating in the NIS. However, in their clinical practice, physicians should attempt to achieve voluntary co-determination of the patient, which we shall deal with below.

\section{A comment regarding 'advocacy'}

As experts, physicians may exaggerate a patient's reduced functional ability in a certificate to achieve what they believe to be in the patients' best interests - a welfare benefit. A physician who describes a patient's restricted functional ability in terms that are more serious than is the case is called the patient's advocate (Solli 2007: 353). Such a breach of the requirement of professionalism and accuracy when writing certificates cannot be justified as beneficence or as ethical in other ways.

\section{Autonomy}

In medical ethics, consideration of the patient's liberty is formulated as the principle of autonomy (Beauchamp \& Childress 2013). This principle means respect for the patient's right to make decisions regarding what is important to his/her life. However, in clinical practice 'autonomy is not likely to mean anything other than codetermination. Patients cannot order their physician to do anything that the physician finds professionally or ethically indefensible [...]' (author translation) (Tranøy 2005: 33). Physicians also have professional autonomy which must be respected. We will now discuss the place of co-determination in social insurance medical practice.

Politically, autonomy often means independence and self-determination. However, autonomy is also defined relationally, based on people living in social relationships and depending on societal structures (Beauchamp \& Childress 2013: 106). Relational autonomy is the ability to make decisions for oneself, through the network of social relationships in which people live (Gulbrandsen and others 2016; Jennings 2016; Meland 2005). Meland (2005: 3443) writes that 'as people, it is possible to make one's own decisions, at the same time that we mutually depend on each other' (author translation). One challenge associated with respecting relational autonomy is distinguishing between the relations that promote a person's independence in a community and the ones that do not (Jennings 2016).

In the event of illness, both the ability to make decisions and to envisage the future can be impacted negatively. We believe that relational autonomy is clinically important, because in a good relationship, a physician should not merely respect the patient's autonomy but should also attempt to foster autonomy in the form of codetermination by offering support and encouragement (Gulbrandsen and others 
2016). SIME research has also shown that respect for autonomy can improve a patient's self-esteem and ability to accomplish more (Lynöe and others 2011).

\section{Social insurance medicine's shared decision-making model}

Research has developed a three-step model for clinical practice in order to achieve co-determination between patient and clinicians. This shared decision-making model is based on the relational autonomy concept (Elwyn and others 2012; Gulbrandsen and others 2016). A similar model has been adopted in Norway, and is known as samvalgsmodellen (Ministry of Health and Care Services 2015: 60). Table 1 describes how the shared decision-making model is used to follow up with people on long-term sick leave. The shared decision-making model improves patients' opportunities for taking responsibility for their own affairs.

Table 1. Social insurance medicine's shared decision-making model used for followup with patients on long-term sick leave

\begin{tabular}{|c|c|}
\hline $\begin{array}{l}\text { Step } 1 \\
\text { Information about } \\
\text { follow-up and } \\
\text { possible choices }\end{array}$ & $\begin{array}{l}\text { The physician gives relevant information about: } \\
\text { - } \text { important milestones in the NIS's follow-up of } \\
\text { people on sick leave, } \\
\text { - } \text { the tasks and responsibilities of patients, } \\
\text { employers and physicians related to improving } \\
\text { their functional ability and capacity for work, } \\
\text { - choices that may arise regarding ways of } \\
\text { continuing to participate in working life or } \\
\text { applying for NIS benefits. }\end{array}$ \\
\hline $\begin{array}{l}\text { Step } 2 \\
\text { Conversations and } \\
\text { discussions of } \\
\text { options }\end{array}$ & $\begin{array}{l}\text { The physician and patient: } \\
\text { - discuss specific situations that have arisen, } \\
\text { - } \quad \text { set out options - and discuss the patient's wishes } \\
\text { and goals going forward, } \\
\text { - draw a picture of the pros and cons of the options } \\
\text { in the short and long term. }\end{array}$ \\
\hline $\begin{array}{l}\text { Step } 3 \\
\text { Conversations } \\
\text { regarding decisions }\end{array}$ & $\begin{array}{l}\text { The patient makes his/her own decisions in the situation } \\
\text { after being allowed to discuss: } \\
\text { - the legal rules, } \\
\text { - what is important or best in his/her own life. }\end{array}$ \\
\hline
\end{tabular}

According to the shared decision-making model, physicians do not only provide information about different options. Physicians can also provide specific advice, based on their knowledge of the patient's abilities and situation. Ethically, it is not problematic to give advice or attempt to convince the patient that some choices are better than others, as long as this takes place in an open dialogue where the physician 'states his/her view [and] the patient receives honest answers to his/her questions' (author translation) (Pedersen, Hofmann and Mangset 2007:1646). 
Let us consider an example: A patient believes that disability pension is what is best for her. The physician may then advise the patient to envision whether this would also be true in a couple of years' time. The physician may go even further and attempt to convince the patient that it would be best for her to delay applying for a disability pension. The physician could then be called paternalistic in the soft sense of the term. 'Soft paternalism means to influence someone in a way that improves their ability to realise their own goals' (author translation) (Wifstad 2013: 135). Even though the patient has received paternalistic advice, she may maintain her right to codetermination by making her own decision as to whether to accept the advice or not.

\section{Social justice}

Each patient at a physician's surgery or visitor to a National Insurance office should be 'treated justly' in the difficult situation he/she might be facing. However, this can be problematic because the person must not only be considered an individual in isolation, but also a member of and participant in a social community. Justice is about evening out competing interests, needs, rights, burdens or obligations between people who collectively constitute a society (Beauchamp \& Childress 2013; Solli 2007: 230f). Justice is thus a complex concept. Justice theory states that both a formal principle of justice and one or more material criteria must be met at the same time in order to ascertain how to treat people equally (Beauchamp \& Childress 2013: 250-53). Arbitrariness is the counterpart to justice (Solli 2007: 232f).

Aristotle formulated the formal concept of justice in a way that is still valid: 'Equals must be treated equally, and unequals must be treated unequally' (Beauchamp \& Childress 2013: 250). This formal principle of justice is abstract - it says nothing about the material criteria that should apply to fair distribution. However, it states that the person whose interests are in question should be treated impartially. Impartiality is a criterion of formal justice (Table 2).

The material criteria explain what should specifically be compared as equal or unequal. They state what to compare and treat equally, such as when different people with the same needs are treated equally. If people's needs are different, then they must be treated differently (Beauchamp \& Childress 2013: 251f). A fair assessment of a case is thus based on two conditions: formal justice from the perspective of impartiality and one or more material criteria that specify what must be distributed equally.

\section{Social justice and its three forms in the National Insurance system}

The idea of the form of justice called social justice arose during the Industrial Revolution at the end of the 19th century and the beginning of the 20th. Social justice includes the following characteristics: a) It addresses a defined social community, often the nation state, where the question of fair distribution of goods is brought up; b) Established institutions - like the NIS - are set up to address this question in such a way that they impact the lives of individuals; and c) A state must exist that can change social institutions and legislation when necessary so that they best serve the people, in line with the ideas of justice supported by the citizens (Miller 1999: 2-7). In a Norwegian context, the National Insurance Act (1997) is a core element of social justice. We will now present the three forms of material justice in the National Insurance system that together constitute its social justice. They are compensatory justice, distributive/redistributive justice and justice as application of legal rules. All the 
forms use the formal principle of justice as a necessary prerequisite for the particular form of justice.

Table 2. The concept of social justice in the National Insurance system

\begin{tabular}{|c|c|c|c|c|}
\hline \multirow{2}{*}{$\begin{array}{l}\text { Social } \\
\text { justice }\end{array}$} & \multirow{2}{*}{$\begin{array}{l}\text { Formal } \\
\text { justice } \\
\text { theory }\end{array}$} & \multicolumn{3}{|c|}{ Material justice theory } \\
\hline & & Compensatory & $\begin{array}{l}\text { Distributive/ } \\
\text { redistributive }\end{array}$ & Legal rule \\
\hline $\begin{array}{l}\text { Criteria for } \\
\text { use of the } \\
\text { concept of } \\
\text { justice in } \\
\text { practice }\end{array}$ & Impartiality & $\begin{array}{l}\text { Personal } \\
\text { injury }\end{array}$ & $\begin{array}{l}\text { Need } \\
\text { - financial security } \\
\text { - help to achieve } \\
\text { improved capacity } \\
\text { for work } \\
\text { Equality } \\
\text { - equal human } \\
\text { dignity } \\
\text { - equalising of } \\
\text { income and living } \\
\text { conditions } \\
\text { - equal right to the } \\
\text { same actual } \\
\text { opportunities for } \\
\text { dignified life and } \\
\text { participation } \\
\text { Desert } \\
\text { - ability to pay } \\
\text { - ability to find work }\end{array}$ & $\begin{array}{l}\text { Illness, } \\
\text { injury, } \\
\text { defect as the } \\
\text { main causes } \\
\text { of loss of } \\
\text { capacity for } \\
\text { work }\end{array}$ \\
\hline
\end{tabular}

\section{Compensatory justice}

Compensatory justice calls for people to be granted compensation when they incur an injury or are disadvantaged. When workers are injured or sick, and therefore unable to work, they must receive compensation. The material criterion is personal injury (Solli 2007: 234) (Table 2).

\section{Distributive/redistributive justice}

Three often used distribution criteria are: need, equality and desert (Solli and others 2005), see Table 2. They can be found in the three purposes in Section 1-1 of the National Insurance Act. The first purpose is 'to provide financial security by securing an income and providing compensation for extra expenses' (author translation) in many of the situations citizens encounter: 'unemployment, pregnancy and childbirth, sole responsibility for children, illness and injury, disability, old age and death' (author translation). The criterion need is expressed here. Kjønstad and others (2017: 40) write that in practice this securing of income for subsistence is the main objective of the National Insurance system' (author translation). In the practice of social insurance medicine, chronic drug addicts, for example, may have complex needs, along with unknown medical ailments. The need criterion motivates physicians to 
make a greater effort to search for relevant medical facts about patients' medical conditions and thus help safeguard their rights.

The second purpose is to contribute to 'equalising income and living conditions during people's lives and between groups of people' (author translation). Insurance and fair economic redistribution come into the picture here. The criterion equality is expressed here in terms of financial distribution and redistribution.

The third purpose is to help people to help themselves in order for people to be able to provide for themselves and manage on their own as best possible on an everyday basis' (author translation). There are two aspects to this purpose. The first aspect 'to help themselves' is a financial principle related to persons meeting their own needs, usually through their own work (Solli 2007: 297f). This principle of selfhelp is closely 'linked to the work-first strategy and the principle of an inclusive working life' (author translation) (Kjønstad and others 2017: 40). 'Self-help' is a specification of the distribution according to the desert criterion. The size of the benefit depends on the efforts made by the citizen to procure an income and pay taxes. The second aspect entails people receiving help to improve their capacity for work when needed, both in the form of work-related rehabilitation provided by the health care services and measures organised by the NIS. This aspect is ambiguous. On the one hand, an offer of help presupposes a requirement that people should try to get back to work. Work training should also be attempted several times. On the other hand, citizens' need for help with work training must be met. Improving a person's capacity for work partly implies a requirement of desert, partly receiving help (Solli and others 2005).

\section{Justice as application of legal rules}

It is of particular importance for citizen welfare that justice be based on legal rules (Kjønstad and others 2017). The most important legal criterion in social insurance medicine is 'illness, injury or defect that is the main cause of loss of the capacity for work' (Table 2) (National Insurance Act 1997: Section 12-6). It is important for physicians to have some knowledge of legal rules and how they should be applied in the actual clinical situation.

To summarise, granting justice to a patient in social insurance medicine entails considering the patient as an equal by impartially, respectfully and with empathetic interest, putting oneself in the patient's place, in terms of the criteria for material justice relative to the legal rules (Table 2).

\section{Writing medical certificates}

Some physicians invite patients on long-term sick leave to give input to the writing of medical certificates about them. One GP describes the practice as follows:

The physician and the patient collaborate on describing and assessing the patient's functional ability. The physician can be honest and clear in his/her assessments, both in relation to the patient and the National Insurance office. The patient is given an opportunity to discuss any of the physician's findings that he/she does not understand, and may give input to the rewriting of any points he/she does not agree with. The physician displays respect by showing the patient the certificate and discussing the information that will be provided (Harald Elvsåshagen, personal communication, 7 June 2018). 
The quote allows us to make the following comments. The patient is invited to help decide what to write about the illness, future treatment, functional ability and capacity for work, and his/her prospects. The physician upholds the patient's dignity by clearly acknowledging his/her perspective and including the patient in a process that has to do with him/herself. The physician consciously attempts to act truthfully and as impartially as possible both towards the patient and the NIS. The physician's practice preserves the physician-patient relationship if the patient's application for a benefit from the NIS is denied. In this way, the physician supports the principle of nonmaleficence. Ultimately, the patient should decide whether to apply for a benefit or not. This is how the principle of co-determination is followed. In this complex situation, the physician should seek to protect the patient's best interests. In the role of expert, the physician is a competent professional who decides what to put in the certificate.

Respect also means that physicians are open to different ways of dealing with issues that may be difficult, like the requirement of a medical condition. GPs can:

- Describe the history of the patient's ailments and current status, based on their knowledge of the patient, and leave it to the NIS to determine whether the requirement of a medical condition has been met or not,

- In the event of a disagreement regarding the medical condition, acknowledge the patient's opinion and agree that views can differ on the patient's condition. The physician will still write what he/she thinks in the certificate, but can record the disagreement. The patient is encouraged to present his/her view in his/her self-declaration to the NIS.

- Refer the patient to a specialist for a second opinion. The trust between the patient and the physician can be preserved this way.

We have now seen how GPs do not view the role of treatment provider and expert as conflicting with each other when writing medical certificates. On the contrary, they may apply and balance the five recognised principles of medical ethics.

\section{The importance of professional standards}

Most importantly, the certificate must be objective and verifiable (Solli \& Barbosa da Silva 2018). In order to determine the premises and draw a conclusion, the physician must know what the National Insurance office needs to know, that is, the purpose of or mandate for the certificate (Code of Ethics for Doctors 2015: IV Rules governing the issuing by doctors of medical certificates and other certified documents, Sections 4 and 5; Rudebeck 2010; Solli 2007: 373-9).

In order to achieve verifiability, it is necessary to have recognised professional standards, partly in order to assess the illness and the functional ability, and partly in order to determine what objective criteria to apply (Toon 1992, Bruusgaard and others 1995; Solli 2003; Solli and others 2005). However, social insurance medicine lacks standards for describing patients' resources (WHO 2001).

Existing standards must also be followed in practice in order to avoid a situation like the one described by Terum and Nergård (1999): Physicians' assessments of patients in terms of the conditions to qualify for disability pension were guided to a great extent by the physicians' private values and morals. The assessments therefore appeared to be arbitrary and partial. 
When writing a certificate, a physician should also weigh the patient's situation against material justice criteria or clarify additional special needs. We have already seen that the need criterion means that people who are occasionally referred to as 'vulnerable' must have their special needs clarified and described. The needs that must be met in order for different people to achieve the same actual opportunity to live a dignified life and participate in society may vary. However, the current declaration form is based on the biomedical illness model, which provides little possibility to describe the patients' individual needs (Solli and others 2005).

\section{The roles of treatment provider and expert: is there an ethical conflict?}

We will now further analyse the two areas in which Mæland's (2016) guide to social insurance medicine asserts that the ethical obligations of the roles of treatment provider and expert are in conflict.

\section{Beneficence and social justice}

Social justice guarantees a distribution of welfare that in principle should be in the best interests of all citizens. This is why a patient should not claim a benefit for him/herself alone that would not also be shared with others in the same ethically relevant situation. The legal rules express the public conditions stipulated by the welfare state in order to receive benefits that guarantee a person's welfare, which also means that some people's applications are denied. In cases where a patient's application has been granted, the patient will be able to find a link between what he/she considers to be his/her best interests in a given situation and the right he/she has been granted. In cases where a patient's application has been denied, however, disagreement may also exist between the patient and the NIS, and possibly also the physician, about what constitutes a fair decision regarding the best interests of the patient. It might not be clear what constitutes the patient's present and future best interests. We thus see that expertise in social insurance medicine plays an important role in protecting the best interests of the patient, that is, his/her welfare, because the patient's condition meets the criteria for social justice. But it is unavoidable that an assessment by the NIS will result in some people's applications for benefits being denied. As noted in the introduction, understanding this situation from an ethical perspective does not require two distinct types of medical ethics. The situation can be assessed by applying SIME principles, as shown above.

More unusual medical conditions may not be covered by existing legal rules. However, this is not a matter of a conflict between ethical principles. The problem may be that legislators should consider drawing up legal rules that are a better fit with people's needs and rights.

\section{The duty of confidentiality and the duty to provide information to the NIS}

Physicians' duty of confidentiality is based on the principles of autonomy and human dignity. It is up to the patient what others may learn about him/her. The patient's integrity and right to privacy must be protected. However, Section 21-4 of the National Insurance Act (1997) states that the NIS nonetheless 'has the right to obtain 
the information necessary in order to check whether conditions have been met for a benefit' (author translation). The NIS' right to obtain the necessary information from physicians takes precedence over individuals' right to confidentiality. However, Section 15 of the Health Personnel Act (1999) states that not all personal and sensitive information should be forwarded to the NIS. It states that reports must 'contain only the information necessary for its intended purpose' (author translation). The physician must thus determine what information is and is not necessary in a certificate.

Physicians' sharing of information with NIS can be justified, based on the consideration of justice. We provide the following explanation: When illness is a condition for exemption from the obligation to provide for oneself, it must be possible to document the illness, based on criteria that are public and democratically enacted in legislation. This means that a public institution like the NIS requires documentation from a physician in order to assess the citizen's case. From the perspective of the citizens, the socially just welfare provided by the National Insurance system appears to be worth the price associated with the duty to provide information. The transfer of information about the patient to the NIS serves the patient's welfare. It can also be claimed that applying for a benefit from the NIS entails implicit consent to such information sharing. There are therefore no ethical conflicts between the duty of confidentiality and the duty to provide information to the NIS. Ethics can be further served by letting patients participate in the writing of particularly sensitive statements.

Occasionally, a situation occurs where a patient applies for a benefit which is contingent on illness. The patient has a medical condition that may have a particular stigma attached to it, and therefore insists that the GP should not disclose this information to the National Insurance office - for example, he/she knows that a neighbour works at this office. The physician should advise the patient that the application may therefore be denied. The physician can explain the ethical situation facing the patient by using the analysis above. It is also unreasonable for the NIS, which will be paying the benefit, not to receive information about the patient's condition. GPs may find such situations difficult, but this hardly constitutes a conflict of medical ethics.

\section{Conclusion}

This study has argued in favour of a SIME where the ethical duties that follow from the roles of treatment provider and expert can be understood and analysed within the frames of recognised principles of medical ethics. One particular characteristic of SIME is that the obligations associated with the role of treatment provider are expanded to include a wider societal context, based on impartiality and social justice. In this context, the physician should try to balance the treatment provider's sympathy with empathy, maintaining impartiality as a prerequisite for good social insurance medicine practices.

Respect for human dignity is the overarching principle of SIME. The four other principles are nonmaleficence, beneficence (including soft paternalism), autonomy, and social justice. We have shown that the inherent paternalism of welfare state does not conflict with the patient's right to co-determination. We have not found any basic ethical conflict between beneficence in the role of treatment provider and the principle of justice in the role of expert. The obligation to provide information to the 
NIS appears to be justified, based on the consideration of social justice applied to all citizens.

We do not see that the duties of the physician's role as a treatment provider conflict with his/her duties as an expert in writing medical certificates for the NIS. To the best of our knowledge, ethical problems that arise are more likely to be a matter of differing views on how ethical principles should be applied in particular situations. Problems may necessitate the physician and the patient entering into negotiations about the specific options available. Physicians must be familiar with ethics in order to communicate with patients about the values that are at risk during social insurance medicine consultations.

\section{Acknowledgements}

We want to thank Jens Egeland and Sverre Blaasvær, Harald Elvsåshagen, and Nina Thunold Reime, for rewarding input into the writing process. Thanks to the librarians at Vestfold Hospital and to Akasie språktjenester and Cristina Pulido Ulvang for the translation into English. We also want to thank the anonymous reviewer of The Nordic Journal for Applied Ethics for insightful, constructive critique. Vestfold Hospital Trust financed this research project, and Norsk trygdemedisinsk forening funded the translation.

\section{References}

Beauchamp, T. L., Childress, J. F. (2013). Principles of Biomedical Ethics (7. ed.) New York and Oxford: Oxford University Press.

Bruusgaard, D. (1996). Pasientens advokat eller velferdsstatens vokter? Tidsskr Nor Lageforen, 116: 2455-2457. https://tidsskriftet.no/1996/08/artikkel/pasientensadvokat-eller-velferdsstatens-vokter

Bruusgaard, D., Heiberg, A. N., Lie, R. K., Malterud, K., Noreik, K. \& Westin, S. (1995). Sykdomsbegrepet $i$ Folketrygden (\$8-3). Konsensusrapport til Trygderetten. Rapport 95:2. Oslo: Gruppe for trygdemedisin, Universitetet i Oslo.

Code of Ethics for Doctors (2015). Den norske legeforening. Retrieved October 08, 2019, from https://legeforeningen.no/Om-Legeforeningen/Organisasjonen/ Rad-og-utvalg/Organisasjonspolitiske-utvalg/etikk/Code-of-Ethics-forDoctors-/

Dworkin, G. (1999). Paternalism. In Beauchamp D. \& Steinbock B. (eds.). New Ethics for the Public's Health (pp. 115-128). New York: Oxford University Press.

Elwyn, G., Frosch, D., Thomson, R., Joseph-Williams, N., Loyd, A., Kinnersley P., ... Barry M. (2012). Shared Decision Making: A Model for Clinical Practice. J Gen Intern Med, 27(10), 1361-1367. https://doi.org/10.1007/s11606-012-2077-6

Gough, I. (2017). Heat, Greed and Human Need. Climate Change, Capitalism and Sustainable Wellbeing. Cheltenham: Edward Elgar Publishing. https://doi.org/10.4337/9781785365119

Gulbrandsen, P., Clayman, M. L., Beach, M. C., Han, P. K., Boss, E. F., Ofstad, E. H. \& Elwyn, G. (2016). Shared decision-making as an existential journey: Aiming for restored autonomous capacity. Patient Education and Counseling, 99, 15051510. https://doi.org/10.1016/j.pec.2016.07.014 
Health Personnel Act (1999). Lov om helsepersonell m.v. (LOV-1999-07-02-64). Retrieved October 08, 2019, from https://lovdata.no/dokument/NL/lov/199907-02-64

Jennings, B. (2016). Reconceptualizing Autonomy: A Relational Turn in Bioethics. Hastings Center Report, 46 (3): 11-16. https://doi.org/10.1002/hast.544

Kjønstad, A., Syse A. \& Kjelland M. (2017). Velferdsrett I. Grunnleggende rettigheter, rettssikkerhet og tvang (6. ed.). Oslo: Gyldendal Juridisk.

Lynöe, N., Wessel, M., Olsson, D., Alexanderson, K. \& Helgesson, G. (2011). Respectful encounters and return to work: empirical study of long-term sicklisted patients' experiences of Swedish healthcare. BMJ Open, https://bmjopen.bmj.com/content/1/2/e000246

Meland, E. (2005). Gjensidig respekt heller enn omsorgsfull godhet. Tidsskr Nor Logeforen, 125: 3442-3443. https://tidsskriftet.no/2005/12/kronikk/gjensidigrespekt-heller-enn-omsorgsfull-godhet

Miller, D. (1999). Principles of Social Justice. Cambridge (MA): Harvard University Press.

Ministry of Health and Care Services (2015). Helse- og omsorgsdepartementet. Nasjonal helse- og sykehusplan (2016-2019). (Meld. St. 11 (2015-16)). Retrieved October 08, 2019, from https://www.regjeringen.no/contentassets/ 7b6ad7e0ef1a403d97958bcb34478609/no/pdfs/stm201520160011000dddpdfs. pdf

Mæland, J. G. (2016). Veileder i trygdemedisin (9. ed.). Oslo: Gyldendal Akademisk.

National Insurance Act (1997). Lov om folketrygd (LOV-1997-02-28-19). Retrieved October 08, 2019, from https://lovdata.no/lov/1997-02-28-19

Nordenfelt, L. (2004). The Varieties of Dignity. Health Care Analysis, 12(2): 69-81. https://doi.org/10.1023/b:hcan.0000041183.78435.4b

Nüchtern, E., Bahemann A., Egdmann W., van Essen J., Gostomzyk J., Hemmrich K., ....von Mittelsstaedt G. (2015). Soziale Sicherheit braucht Sozialmedizin. Selbsverständnis von Ärztinnen und Ärzten in der sozialmedizinischen Begutachtung und Beratung. Gesundheitswesen, 77, 580-585. https://doi.org/10.1055/s-0035-1555897

Pedersen, R., Hofmann, B. \& Mangset M. (2007). Pasientautonomi og informert samtykke i klinisk arbeid. Tidsskr Nor Legeforen, 127, 1644-1647. https://tidsskriftet.no/2007/06/oversiktsartikkel/pasientautonomi-oginformert-samtykke-i-klinisk-arbeid

Rudebeck, C. E. (2010). Läkarkåren och sjukskrivningarna. Läkartidningen, 107 (9): 592- 595.

Seger, W. \& Nüchtern, E. (2015). Physicians' Self-Conceptions of Their Expertise in Statutory Health Insurance and Social Security Systems. Electron Physician. http://dx.doi.org/10.14661/2015.1092-1094

Silverman, J., Kurtz, S. \& Draper, J. (2013). Skills for Communicating with Patients. London: Radcliffe Publishing. https://doi.org/10.1201/9781910227268

Solli, H. M. (2003). Medisinsk sakkyndighet, objektivitet og rettferdighet i uførepensjonssaker. Tidsskr Nor Logeforen, 123, 2072-2075. https://tidsskriftet.no/2003/08/om-helsetjenesten/medisinsk-sakkyndighetobjektivitet-og-rettferdighet-i-uforepensjonssaker

Solli, H. M. (2007). Rettferdighet og objektivitet $i$ trygdemedisinske uførhetsvurderinger. En etisk og vitenskapsfilosofisk analyse av tre 
uførhetsmodeller $i$ et historisk perspektiv. (Doctoral dissertation, with English summary, University of Oslo). Oslo: University of Oslo. http://michaelquarterly.no/index.php?seks_id=117258\&a=1\&treeRoot=11720 2

Solli, H. M., Barbosa da Silva, A. (2018). Objectivity applied to embodied subjects in health care and social security: definition of a comprehensive concept of cognitive objectivity and criteria for its application. BMC Medical Ethics. https://doi.org/10.1186/s12910-018-0254-9

Solli, H. M., Barbosa da Silva, A., Lie, R. K., \& Bruusgaard, D. (2005). Biomedisinsk sykdomsmodell og rettferdig fordeling av uførepensjon. Tidsskr Nor Loegeforen, 125, 3293-3296. https://tidsskriftet.no/2005/12/om-helsetjenesten/biomedi sinsk-sykdomsmodell-og-rettferdig-fordeling-av-uforepensjon

Steigleder, K. (2014). Human dignity and social welfare. In Düwell M., Braarvig J, Brownsword R \& Mieth D (eds.). The Cambridge Handbook of Human Dignity (pp. 471-476). Cambridge: Cambridge University Press. https://doi.org/ $10.1017 /$ cbo9780511979033.059

Steihaug, S., Gulbrandsen, P. \& Werner, A. (2012). Recognition can leave room for disagreement in the doctor-patient consultation. Patient Education and Counseling, 86, 316-321. https://doi.org/10.1016/j.pec.2011.06.011

Terum, L. I. \& Nergård T.B. (1999). Medisinsk skjønn og rettstryggleik. Legar som portvakter i fordelinga av offentlege goder. Tidsskr Nor Logeforen, 119, 21922196. https://tidsskriftet.no/1999/06/artikkel/medisinsk-skjonn-og-rettstrygg leik

Tomasello, M. (2016). A Natural History of Human Morality. Cambridge (MA): Harvard University Press. https://doi.org/10.4159/9780674915855

Toon, P. D. (1992). Ethical aspects of medical certification by general practitioners. British Journal of General Practice, 42: 486-488.

Tranøy, K. E. (2005). Medisinsk etikk $i$ vår tid (4. ed.). Bergen, Fagbokforlaget.

UNESCO (2005). Universal Declaration on Bioethics and Human Rights. Retrieved October 08, from http://unesdoc.unesco.org/images/0014/001461/146180E.pdf

Waddell, G. \& Burton A.K. (2006). Is work good for your health and well-being? London: TSO.

Westrin, C.-G. \& Nilstun T. (2002). Försäkringsmedicin och etik. In Järvholm B. \& Olofsson C. (eds.). Försäkringsmedicin (pp. 223-241). Lund: Studentlitteratur.

WHO. (2001). International Classification of Functioning, Disability and Health. ICF. Geneva: World Health Organization. Retrieved October 08, 2019, from https://www.who.int/classifications/icf/en/

Wifstad, Å. (2013). Helsefagenes etikk. En innføring. Oslo: Universitetsforlaget.

Wynne-Jones, G., Mallen, C. D., Main, C. J. \& Dunn, K. M. (2010). What do GP's feel about sickness certification? A systematic search and narrative review. Scandinavian Journal of Primary Health Care, 28, 6775. https://doi.org/10.3109/02813431003696189 